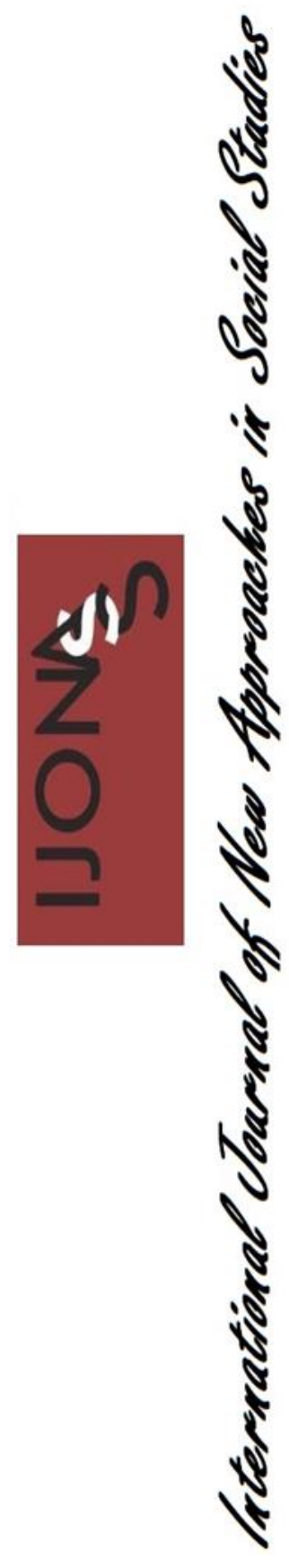

\title{
Etnik Kimlik, Savaş ve Göç Olgularının Çocuklar ve Ergenler Üzerindeki Psikolojik Etkileri
}

\author{
Musa EROĞLU ${ }^{1 *}$ \\ Gönderilme Tarihi:17 Nisan 2020 \\ Kabul Tarihi: 16 Haziran 2020 \\ DOI: $10.38015 /$ sbyy. 721964
}

\begin{abstract}
$\ddot{O} z:$
Savaş ve çatışmalarda en fazla zarar gören ve bir o kadar da masum olanlar hiç şüphesiz çocuklardır. Yüzyıllardır dünyada milyonlarca çocuk savaşların çatışmaların ve terör eylemlerinin etkisiyle mağdur olmaktadırlar. Bu savaş ve çatışmaların çocuklar üzerindeki olumsuz etkileri; sakat kalma, öldürülme, ebeveynlerin yada yakınlarının yaralanması veya öldürülmesi olarak ele alınabilir. Bunun yanında fiziksel, psikolojik ve cinsel şiddet görme, asker olarak çatışmalarda kullanılma, zorunlu bir göçe maruz kalma, göç edilen bölgelerde kötü muamele görme, dişlanma, ötekileştirilme, aşırı politik ve milliyetçi eğilimlere sahip olma, hastalık, yoksulluk, yeteri kadar beslenememe de savaş ve çatışmaların çocuklar üzerindeki diğer etkileri olarak sıralanabilir. Göç yaşayan çocukların ev ve okul ortamına uyumlarında problem yaşamaları da olasıdır. Bu çalışmada etnik kimlik sorunları savaşa ve zorunlu göçe maruz kalmış çocukların neler yaşayabileceği dile getirilmeye çalışılmıştır. Bu çalışmayla savaşa maruz kalmış ve göçe zorlanmiş çocukların yaşayacakları problemlerin topluma anlatılarak toplumun bilinçlendirilmesi amaçlanmıştır.
\end{abstract}

Anahtar Kelimeler: Savaşve çocuklar, savaşve göç, zorunlu göç, etnik kimlik.

\begin{abstract}
:
Without any doubt, children are the most innocent and also the most disadvantaged ones, suffering in wars and clashes Millions of children havebeen becoming victims of wars, fights and terrorist attacks. The negative effects of these war and clashes on children can be said to bedeath, disabilities, losing their parents or injury the parents, physical, psychological and sexual violence, being forced to fight as a soldier, obligatory immigration and insufficient conditions in the new living area, sickness, poverty and facing malnutrition. Also there may be adjustment problems in the social and school life of the immigrant children. In this research, it is aimed to explain the problems of the children, who suffer from ethnical identity problems and face the obligatory migration and war conditions. It is also aimed to make people aware of the problems that children can experience due to wars and obligatory immigration.
\end{abstract}

Keywords: Wars and children, wars and migration, forced migration, ethnic identity

\footnotetext{
${ }^{1}$ Mersin Üniversitesi, Türkiye. Orcid ID: 0000-0001-7588-6385

*Sorumlu Yazar (Corresponding Author): eroglumusa33@gmail.com
} 


\section{GíRIŞ}

Çocukluk dönemi insanların yaşamında çok önemli bir yere sahiptir. Çocukluk dönemi kendisinden sonra gelen dönemlere de şekil veren bir dönem olarak da değerlendirilebilir. Çünkü bu dönem gerek aile içerisindeki ve gerekse aile dişındaki ilişkilerimizi belirleyen, sevgi ve nefret gibi duyguların oluştuğu meslek seçiminin belirlendiği etrafımızdaki insanlar hakkında ve kendi hakkımızda kararlar verdiğimiz bir süreçtir. Bu sebeple, suç işlemeye itilen, yasadışı olaylara karışan çocukların neredeyse tamamının geçmişlerine bakıldığında acı olayların izleri olduğu görülecektir. Bu gün dünyada milyonlarca çocuk, bir şekilde doğrudan veya dolaylı olarak, savaş ve terör olaylarına maruz kalıp bu olayların kurbanı durumuna gelmektedir. Hakları ve ihtiyaçları savaş ihtiyaçlarından daha önemsiz görülen bu sessiz ve masum grup hiçbir şekilde anlam verilemeyen bir yıkımın ve yıkıcılığın getirmiş olduğu yok olma tehdidiyle karşı karşıyadır. Ülkeler arasındaki siyasi ve politik çatışmalar, ülkelerin kendi içlerindeki hesaplaşmaları ve terör eylemleri çocukların ölmelerine neden olmakta, çocuklarda fiziksel ve ruhsal hasar bırakabilmektedir. Bu durumlarda yüz binlerce çocuk anne babasını ve yakınlarını kaybetmekte, bunun yanısıra fiziksel, duygusal yada cinsel istismara maruz kalmaktadırlar (Erden ve Gürdil,2009). Savaş kaynaklı ortaya çıkan mecburi göç, işkence gibi bireye zarar veren ve bireyde tahribat yaratan bir etkiye sahip olabilmektedir. Bu tahribatlarm etkisi göç yaşamak zorunda kalan bireyin göç sırasında kendisine ya da sevdiği kişilere yönelik maddi veya manevi değerleri sarsıcı bir tehdit veya eylem olduğunda fazlasıyla artış göstermektedir. Göç esnasında eziyetle birlikte, fiziksel ya da ruhsal birçok travmatik tecrübe de yaşanabilmektedir. Travma sayısı arttıkça, tepkiler ve buna bağlı olarak özellikle anksiyete bozuklukları çok fazla artmaktadır. Zorunlu göçemaruz kalmış mağdurlarla ilgili yapılan araştırmalarda, (Baş ve Molu,2017, Akıllı ve Dirikoç,2015) yaşam şartlarının değişmesinden en çok etkilenenlerin kadın ve çocuklar olduğu tespit edilmiştir. Göç sonrası ailelerde çocuklar ve kadınlar hayatlarını devam ettirebilmek için çalışmak mecburiyetinde kalırken, kadınların büyük çoğunluğunun göç sebebiyle sosyal çevrelerini kaybettiklerinden, aile ve akrabalarından uzak kaldıklarındanşikâyetçi oldukları, ileri ve orta yaşlı kadınların yeni yerleştikleri yerlereuyum konusunda güçlük çektikleri, psikolojik sorunlarında artış olduğu, daha gergin ve stresli oldukları ve sıklıkla baş ağrısı sorunu, yaşadıkları görülmektedir. Göç eden topluluklar içinde yalnızca iş hayatına atılmış genç kızların yeni yaşam şartlarına adapte olmadadiğer bireylere oranla başarılarının daha yüksek olduğu görülmüştür (Bilgin,2014).

Diğer yandan etnik kimlik kavramıda savaş ve göç olgusu içerisinde çok önemli bir konudur. Çocuk psikolojisi etnik bilincin nasıl geliştiğini anlayabilmek için başvurulabilecek en güvenilir ve en doğru kaynaktır. Çocukta "ben" ve "diğerleri” ya da "öteki" kavramlarının nasıl bir gelişim gösterdiğinin bilinmesi bu konuda bize ışık tutacaktır. Tarihi olaylar ve kırgınlıklar etnik kimliğin biçimlenmesinde ve bu etnik kümeler arasındaki ilişkilerin canlılığında önemli bir yere sahiptir. Birbirine yakın grupların psikolojisinde insanları "biz" ve "onlar" diyeayıran bir ayrım dürtüsünün insanlık tarihinin başlangıç dönemde bile var olduğu bilinmektedir. Etnik kimlik bilinci ve kişinin kendi kimliğinin farkına varması, nesilden nesile taşınan kültürel mirasın zamanla yoğrulmasıyla oluşur. Günümüzde etnik kimlik bireysel kimliğin temel yap1 taşını oluşturmaktadır. Birbirleriyle kaynaşan bütün bu bir bütünün ayrılamaz özellikleri olmuşturlar (Çevik, 2008). 


\section{YÖNTEM}

$\mathrm{Bu}$ araştırma nitel bir araştırmadır. Araştırmanın konusu ve kapsamı gereği "yayınlanmış" veri kaynaklarından yararlanılmıştır. Araştırmanın durum çalışması saptamasına yönelik nitel boyutunda doküman analizi tekniğinden, yararlanılmıştır. Konuyla ilgili olarak yayınlanan İngilizce yazılmış, İngilizceden Türkçeye çevrilmiş kaynaklardan yararlanılmış ve bu araştırmada doküman analizi modeli kullanılmıştır.

Doküman analizi, araştırmacının çalıştığı konuyla ilgili kişi veya kurumlara doğrudan ulaşamayacağı durumlarda önemli bir bilgi toplama yöntemi olarak karşımıza çıkar. Tarihsel olay, olgu, kültür veya geleneklere ilişkin dokümanlar kadar, yaşadığımız zamana ait dokümanlar, kaynağı belli olmayan anonim dokümanlar veya kaynağı belli olan ilgili dokümanlar bir veri kaynağı oluşturur. Diğer nitel veri toplama yöntemleriyle karşılaştırıldığında doküman analizi, görüşme ve gözlem gibi çalışmalarda karşımıza çıkan denek veya 'katılımcı tepkiselliği' sorununa yol açmaz. Araştırmacı ve araştırmaya katılan bireyler arasında doğrudan fiziksel, davranışsal ve duygusal etkileşimler olmaz. Doküman analizi tıpkı gözlem yöntemi gibi, uzun süreli araştırmalarda etkili olarak kullanılabilir (Bogdan ve Biklen, 1982).

Gözlem yöntemine benzer olarak, doküman analizi bireye özgü davranış ve duyguların, araştırmacının belirlediği bir zamanda kaydedilmesi yerine, oluştuğu anda ve bireyin kendisi tarafından özgün bir şekilde kaydedilmesi temeline dayanır (Forster,1994).

Doküman incelemesi yaparken izlenebilecek bir dizi aşama vardır. Her araştırmacı bu aşamaları araştırma probleminin niteliğine, doküman incelemesi sonucunda elde etmeyi hedeflediği veriye veya dokümanları ne kadar kapsamlı ve derinlemesine incelemesine bağlı olarak yeniden yorumlayabilir (Yıldırım ve Şimşek, 2006).

\section{BULGULAR}

\section{Etnik Kimlik}

Kimlik konusu ilk olarak bireyin seçimlerini yapabilen bir birey olarak kabul edilmesini gerekli kıldığı için bireyselleşmeye yönelik bir takımteorik bilgileri vurgulamak yararlı olacaktır. Batı ülkelerinde Ortaçağın bitimiyle başlayan Yeniçağ beraberinde günümüze kadar ilerleyişini güçlü bir şekilde devam ettiren; özgür, kendi kendine yetebilen ve değerlerini kendi belirleyen bir birey anlayışını getirmiştir. Dumont, yaşadığı toplumdan önemli ölçüde ayrı, atomist bir birey tipinin tarihte görülmemiş bir şey olduğu fakat modern zamanlarda ortaya çıkan özelliklede ahlaki bir kavram olduğu kanaatindedir. Öyle ki günümüzde doğanın ve toplumun hakları ikinci planda kalırken bireyin temel hakları bu haklardan üstün tutulmuştur (Özcan, 2012).

Ortak düşmana sahip olmak yada ortak bir düşman yaratmak etnik ve dini kimliğin oluşmasında kuşkusuz en önemli faktörlerdir. Gallner pozitif ve negatif iki etkinin grupların-milletlerin oluşmasındaki öneminden özellikle bahseder. İlkidayanışma, gönüllülük, özdeşleşme ve irade gibi pozitif duygular. İkincisi ise zorlama, mecburiyet ve korkugibi negatif etkenlerdir. Fakat bu iki etkeni yan yana getirebilen gruplar uzun ömürlü ve sağlam gruplar meydana getirebilir. Renan buna "birlikte acı çekmiş olmak" derve yaşananortak acının "insanları bir araya getirmede zaferlerden daha etkili" olduğunu söylemektedir. Çağdaş milletler ve kimliklerin kendilerini tanımlarken sürekli bir "öteki” bulma güdüsü, “öteki” yoksa da bunu ortaya çıkarma 
çabası bu düzlemde yorumlanabilir. İletişim araçlarının kültürleri yeryüzüne iyi yada kötü ayırt etmeksizin tanıttığı çağımızda ve çoğulcu toplumlarda yersiz yurtsuz toplulukların; bir ırka, bir kültüre ve bir dine dayanarak kendilerini tanımlamaları dini-etnik kimlikleri oluşturmuştur ve bu oluşumun yaygın olarak kullanılması sonucunu doğurmuştur (Akt. Yanmış ve Kahraman, 2014).

Azınlığa üye olan ergenlik dönemindeki bireyler, özellikle de beyaz kültürün hakim olduğu bir toplum içerisinde yaşayan ten rengi olan gençler, ergenlik döneminde kimlik oluştururken başka bir görev daha karşılarına çıkar. Bu ergenler kendilerini belirli bir grupla özdeşleştirmek, grubun değerlerine ve tutumlarına bağlanmak, etnik ya da ırksal bir kimlik geliştirmek zorunda hissederler. $\mathrm{Bu}$ şekilde kendini özdeşleştirme uğraşının bir bölümü çocukluk döneminin ortalarında gerçekleşir. Henüz 7 ile 8 yaşlarında olan azınlık çocukları kendileri ile çoğunluk gruba ait çocuklar arasındaki farkı anlayabilirler ve genelde kendi alt grupları ile kaynaşmayı tercih ederler. Ergenlik dönemine gelindiğinde etnik kimlik sürecindeki öteki adımlar atılmaya başlar. Phinney (2001) tam etnik kimlik gelişiminin ergenlik döneminde üç zorlu evreden geçtiğini savunur. Birinci evre incelenmemiş etnik kimlik evresi Marcia'nın ipotekli kimlik statüsü ile eş değerdir. Marcia (1994) ipotekli kimliği tanımlarken; 'Kişi herhangi bir kriz yaşamadan bağlanma gerçekleştirmiştir. Eski konumlar yeniden değerlendirilmemiş, bunun yerine genç sadece ailesi ya da kültürü tarafından tanımlanmış bir bağlanmayı kabul etmiştir." ABD toplumundaki Afrika kökenli Amerikalı ya da Kızılderili gibi bazı alt gruplarda daha geniş kültürde yaygın olan olumsuz imgeler ve stereotipler, tipik olarak incelenmemiş kimlik içerisinde yer alır. Gerçekten de, ergenlik döneminde bilişsel derinlemesine düşünme ve yorumlama becerilerinin gelişmesiyle birlikte gençler ait oldukları grubun çoğunluk tarafından nasıl algılandığını anlayabilirler (Akt. Bee ve Boyd,2009). Phinney' in (2001) modelindeki ikinci evre etnik kimlik anlayışı, genelde bu arayışı etnik kökenle ilgili bir deneyim tetikler bu deneyim örneğin bariz bir ön yargıyla karşılaşmakta olabilir, lise hayatında daha önceden alışılandan farklı deneyimler yaşamak da. Bu noktada ergen kendi yargılarını oluşturmaya başlar. Bu keşif sürecini çatışma ve çelişkilerin çözülmesi izler. Bu da Marcia'nın başarılı kimlik statüsüne benzer, Marcia (1994) başarılı kimlik için ' Genç krizi atlatmış ve ideolojik ya da mesleki hedeflerine bağlanmayı başarmıştır." demiştir. Genellikle bu döneme Prentice ve Miller'ın (2002) evdeki stereotipler olarak adlandırdığı zorlu bir süreç eşlik eder. Bu stereotipler bir grup üyesinin kendini aynı grubun diğer üyelerine nasıl sunması gerektiği ile ilgilidir. Buna göre kişinin inançları grubun inançlarından farklı olsa bile kabul görmek için belli davranışları benimsemesi gerekir. Örneğin Afrika kökenli Amerikalı bir çocuk aynı etnik birlikten yaşıtları arasına kabul edilmek için beyaz çocuklara belirli bir şekilde davranması gerektiğini öğrenebilir. Latin Amerikalı ergenlerde de aynı durum sıkça yaşanır. Bazıları kendi 1rksal yada etnik grubuyla arasına mesafe koyarak bu baskıdan kurtulmaya çalışırken bazıları da hem çoğunluk hem de azınlık kültürünün çeşitli yönlerini benimseyerek bir orta yol bulmaya çalışırlar. Phinney (2001) bu örüntüyü ' 'karma çift kültürlü kimlik' olarak adlandırır. Bazıları da bu durumla başa çıkmak için temelde iki kültür yaratır. Phinney bu örüntüyü ' dalgalı çift kültürlü kimlik”' olarak adlandırır (Akt. Bee ve Boyd,2009).

\section{Savaş ve Göç}

Göç insana dair küresel bir fenomendir. Tarih boyunca insanlar ve topluluklar savaş, kıtlık, sığınma yada iş bulma gibi sayısız nedenlerle bir yerden başka bir yere göç etmişlerdir. Sosyal bir olay olarak göç sosyal bilimciler tarafından etraflıca çalışılmıştır. Yürütülen birçok araştırma, göçe makro analiz düzeyinde yaklaşmış ve özellikle sosyal, politik ve ekonomik yönlerine eğilmiştir. İnsan odaklı olmasına rağmen göç üzerine yapılan psikolojik çalışmalar daha çok yeni olması düşündürücüdür (Kağıtçıbaşı,2012). 
Göç tarihinin başlangıcı neredeyse insanlık tarihinin başlangıcı kadar eskidir ve dünyada göç her zaman gündemdeki yerini korumuştur. Tarih boyunca meydana gelen göçler Dünyanın günümüzdeki nüfus dağılımını, kültürel ve ekonomik açıdan gelişimini ve sosyo-ekonomik bakımdan yapısını şekillendiren en temel faktördür. Eski çağlardan bu yana var olan göç olgusu, teknolojinin ve ulaşım ağını gelişmesiyle günümüzde mesafesini ciddi bir oranda çoğaltmış, hızlanmış ve geçmişe oranla günümüzde daha da kitleselleşmiştir. İnsanlar ülkelerini ya da bölgelerini ne sebeple terk ederse etsinler, ya da yerleştikleri yerde karşılanma şekilleri nasıl olursa olsun, özellikleri ve dereceleri farklı olsa da mutlaka adaptasyon problemleri yaşamaktadırlar. Göç edenlerin ruhsal ve fiziksel durumları hem kültürel ve psikolojik etkenlerden hem de çevrelerini meydana getiren çevresel, coğrafi ve iklimsel değişimlerden etkilenebilmektedir. Göçle beraber yeni bir çevreye giren insanlar bulundukları yerin lisanını öğrenmede, yeni bir kültürün getirilerine uyum sağlamada ve tamamıyla farklı bir yaşam tarzına alışmada derecesi kişiden kişiye farklılık gösterse de çeşitli güçlüklerle karşı karşıya gelebilmektedirler. Göç eden bireylerin ve mültecilerin birçoğu göç etme konusunda yüksek motivasyona sahip olmalarına, esnek olmalarına ve ilk karşılaştıkları zorlukların üstesinden gelmede ciddi bir yol kat etmelerine karşın; yine de bazılarında göçten önceki süreçteki yaşadıkları eziyet düzeyindeki travmatik ve sarsıcı çeşitli deneyimlerden kaynaklanan psikolojik rahatsızlıklar ve stres gözlenmektedir. Göç edilen ülkedeki hükümet ve yerli halkın tutumu, göç politikaları, mülteci ve göçmenlere yönelik destek programları ve göçmenlerin fiziksel ve ruh sağlığına yönelik adapte edici tüm etkenler sığınmacı ve göçmenlerin yerleştikleri bölgedeki uyumunda oldukça etkilidir(Gün,2006).göçmenlerin ve mültecilerin göç sonrasında yerleştikleri bölgelerde kendileriyle benzer özellikler gösteren kişilerle karşılaşmaları ve bir arada bulunmaları bu kişilere ulaşabilecek sosyal destek ve yardımın artmasını sağlar, buna bağlı olarak psikolojik rahatsızlıklara yakalanma sıklığını azaltabileceği öne sürülmektedir. Bhugra ve Arya, (2009) kişilerin göç ettikleri bölge veya ülkedeki yerleşim yerlerinde ne kadar kendi kültürlerine benzer bir yer bulabildilerse o kadar sağlıklı olduklarına işaret etmektedirler. $\mathrm{Bu}$ açıdan ele alındığında ev sahibinin kültürü ve göçmenin kültürü arasında bir köprü kurulabilmesi ve bir uyum yakalanabilmesi son derece önem teşkil eden bir etkendir. Uzmanlar ve konu üzerine araştırma yapan bireyler ortak bir hayat tarzına sahip mültecilerin bireyci bir kültür içerisine göç faaliyetinde bulunmalarının aksi durumdan daha yüksek bir risk faktörü meydana getirdiğini öne sürmektedirler (Kuşdil,2014).

Çatışmalar ve savaş sebebiyle ülkelerinden, bölgelerinden ya da hanelerinden ayrılmak durumunda kalan, göç sebebi ile mağdur olan aileler ve çocuklar için yeterli oranda destek hizmeti sağlanamamaktadır, bu da göç mağdurlarının ayrımcılık, yoksulluk, barınacak yer, sağlık ve eğitim sorunları gibi konularda yetersizlikler yaşamalarına neden olmaktadır. Bu yetersizlikler suç ve şiddet kültürüne sahip gruplara katılmak veya bu grupların hedefi olup mağdur olmak ve politik açıdan kısır döngülerin görüldüğü topluluklarda bulunmak gibi riskleri beraberinde getirmektedir (Akt. Bilgin,2014). Göç olayının temeline inildiğinde bireyin bir grup yada topluluğa aidiyet hissini kaybetmesine yol açtı̆̆ı söylenebilir. Başka bir açıdan ise adapte olunan kültürel yaşamın ve geleneklerin terk edilmesine yol açmasından ötürü göçün bireydeki psikolojik etkilerinin oldukça sarsıcı olduğu tahmin edilebilir. Yeni göç edilen bölgelerde bu kayıplarla birlikte yalnızlık hissi, sosyal rol ve kültürel statüdeki farklılık, kültürel değerlerdeki belirsizlik durumu ve bu belirsizliğin sebep olduğu kültürel şok göç eden bireylerde ve topluluklarda meydana gelen strese ve psikolojik bozuklukları gösteren faktörlerdir (Balcıoğlu ve Samuk2002). İnsanlar üzerindeki bu tip strese neden olan faktörler söz konusu aile olunca daha karmaşık bir hal almaktadır. Göç olayı bireyleri çevresel faktörlerin, işin ve işyerinin değişikliği, aile bireylerinden geçici ya da sürekli uzak kalma, yaşam şeklinin farklılaşması, okulun değişmesi, maddi durumdaki değişiklik gibi stres 
faktörlerini tecrübe etmek mecburiyetinde bırakmaktadır. Söz konusu stres faktörünün etkileri ailenin gelişimsel görevlerini normalden daha karmaşık bir hale getirmektedir. Birey ve ailelerde göçten sonra uyum ve bağlanma problemleri stres, anksiyete, duygu ve durum karmaşası, madde bağımlılığı ve buna benzer tramvaya bağlı birçok sorun meydana geldiği araştırmalarla ortaya konulmuştur (Akt. Uluocak,2009).

Savaş ve çatışmaların görüldüğü kaos ortamlarının çocuklar üzerindeki hem fiziksel hem de sosyal etkiyi açıkça görmek mümkündür. Bununla beraber savaşın negatif etkilerine direkt maruz kalan, savaşlarda çatışmalara şahit olan yada kaos ortamında bulunan çocukların şiddetli korku veya çaresizlik gibi psikolojik sorunlardan şikayetçi oldukları görülmüştür. Yaşanılan bu korkuların temeli olayların tekrarlanabileceğine, yaralanma yada öldürülme korkusuna, yalnız ve çaresiz kalmaya, yaptıkları hatalar sebebiyle cezalandırılmış olma yada kendilerini suçlama gibi şeylere dayandırılabilir. Savaş ve çatışma gibi olayları birebir yaşamamış ve o ortamda bulunmamış çatışma ve savaş haberlerini radyo ve televizyon gibi medya organları aracılığıyla görmüş çocuklarda da dünyanın güvensiz ve zedeleyici bir yer olduğu mesajını aldıkları için benzer korkular oluşabilir (Erden ve Gürdil,2009).

Bireyin tehlikelerden kendini korumasını ve hayatını devam ettirmesini sağlayan zihinsel mekanizma korku olarak nitelenebilir. Ancak bu korku çok şiddetli bir hale geldiğinde bireyin aklına detaylı bir biçimde işlenmiş olan tehdit edici durum yerini travmatik bir yaşantıya bırakır. Normal gelişim evreleri kesintiye uğratılmış ve güvenden yoksun yetişen çocukların yetişkinlik dönemleri de bu tramvalar nedeni ile risk altındadır. İlerleyen dönemler ele alındığında ise bu tramva ile büyüyen bireylerin psiko-sosyal açıdan sağlıklı bireyler olmaları beklenemez (Erol ve Öner, 1999).

\section{Çocuklarin Yaşlarina Göre Savaş Yaşantisina Tepkileri}

Savaşın neden olduğu travmanın ve tavma sonrası stres bozukluğunun etkisindeki çocuklar uygun bir biçimde incelenip müdahale edilmediğinde etkisini sürdürerek gelişimini olumsuz bir şekilde etkileyebilecek olan birçok tepki gösterebilirler. Çocuğun annesini, babasını, kardeşlerinden birini, yakınlık kurduğu bir aile üyesini, akrabasını, arkadaşını yada öğretmenini kaybetmesi söz konusu ise yas sürecine girmesi kaçınılmazdır (Berger, Pat-Horenczyk, Gelkopf,.2007; Dyregrov, Gjestad, Raundalen, 2000; Graham-Berman ve Seng, 2005).Bununla beraber mekan ve düzen değişiklikleri alışkanlıklara ve ritüellere engeller konulması, sahip olunan eşyaların ve oyuncakların kaybı yaşadığı evden, okuldan, sokağından uzaklaşmış olma ve finansal zorluklarda çocuğu güçten yoksun ve güvensiz bir hale getireceğinden çocukta üzüntü ve yas hissine neden olabilir.Öte yandan kendini suçlu hissetmekte çocuklarda savaşın neden olduğu travma sonrası görülecek bir durumdur. Küçük çocuklar başlarına gelen olaylara yada kayıplarına kendilerinin sebep olduklarını düşünebilirler. Yaş ilerledikçe bu düşünce yerini "bu olanları önlemek için bir şey yapmalıydım” şeklindeki düşüncelere bırakır. Bununla birlikte yakınlarının öldüğü bir ortamdan kurtulan çocuk veya ergenler kurtulamayan yakınlarına karşı suçluluk hissedebilirler ve vicdan azabı çekebilirler. Korku, gergin olma ve irkilme durumları, huzursuz olma, öfke patlamaları ve agresif davranışlar savaş yaşantısının sebep olduğu tavma sonrası stres bozukluğunun diğer etkileri arasında sayılabilirler. Bununla birlikte bireyin olayları tekrar yaşıyormuş hissine kapılması, olayla ilgili kötü düşünceleri zihninde istemeden canlandırması da sıklıkla görülen durumlardır. Ayrıca dikkatin kolaylıkla dağılması, odaklanmada zorluk, uyku problemleri ve kâbus görme, iştahta kesilme yada aşırı yeme ve nedeni belli olmayan fiziksel şikâyetlerinde görülmesi mümkündür. Bunların yanı sıra travmaya sebep olan olayı anımsatan şeylerden kaçınmak, hissizlik, ilgi eksikliği ve gelecek korkusu belirtiler arasında en sık görülenlerdir. Madde kullanımı gibi riskli davranışlara 
yönelmede bu travmatik olayların yol açtığı gerginliği azaltmak amaciyla başvurulacak şeyler arasındadır. Çocuk ve ergenlerde savaş sonrasında meydana gelen bir takım travma tepkileri vardır. $\mathrm{Bu}$ tepkiler genel anlamda her ne kadar benzerlik içerseler de her yaş grubunda gelişimsel özelliklere dayalı bir dizi farklılıklar göstermektedirler (Akt. Erden ve Gürdil,2009).

\section{0-6 yaş okul öncesi dönem çocuklarının travmalara tepkileri}

$\mathrm{Bu}$ dönemdeki çocuklar; temel ihtiyaçlarının giderilmesi, kendilerine ve çevrelerine güven duymaları, ait olunan ortamın ve kişilerin değişime uğramamasının gerekliliği gibi birçok durumda yetişkinlerin desteğine ihtiyaç duyarlar. Çocukların ihtiyaç duyulan desteğin sağlanmaması halinde çocuklarda kendini savunmasız hissetme ve çaresizlik ortaya çıkar. Bunun nedeni ise tehlike ile başa çıkma becerilerinin henüz gelişmemiş olmasıdır (Erden,2000). 0-3 yaş arasındaki dönemde gelişen ve sonraki yıllara yerleşen temel güven duygusu çocuk için ana duygudur. Bu duygu korunma, kollanma, tehlikeli durumlardan ve tehditlerden uzak olma gibi isteklerle kendini gösterir. Bu yaş aralığındaki çocuklarda tüm ihtiyaçların anne tarafından giderilmesi, isteklerin anne tarafından karşılanması ve anneye bağımlılık gibi duygular oluşur. $\mathrm{Bu}$ yaş grubuna yapılan yardım anneye bağımlılık özellikleri ve temel güven duygusunun gelişimi göz önünde bulundurularak yapılmalıdır. Bu yaşlarda çocuğun psikolojik ve fiziksel ihtiyaçlarını düzenli bir şekilde karşılamak tedirginlik hissettikleri durumlarda ise ilgi, temas ve sevgi ihtiyaçlarını zamanında gidermek gerekir. 0-6 yaş grubundaki çocuklar daha önce savaşla ilgili görüntüleri görmemiş ya da konuyla ilgili yapılan yorumlara ve gözlemlere tanık olmamışlarsa diğerlerine nazaran durumdan daha az etkilenirler. 0-6 yaş grubundaki çocukları etkileyen faktörlerin merkezinde anne ve babaların tavır ve tepkileri yer alır. Ebeveynler yaşadıkları durum karşısında korku, çaresizlik ve tedirginlik hissediyorlarsa çocuklar da aynı duruma benzer tepkiler vereceklerdir. Böyle bir durumda anne babanın dikkat etmesi gereken nokta; tepkilerini, çocuğun sahip olduğu güvenlik duygusunu etkilemeyecek bir şekilde dişa vurmak ve bu dişa vurumla birlikte çocuğu gözlemlemek ve takip etmektir. 0-3 yaş aralığındaki bebeklerde travma genelde; ağlama, huzursuzluk, uyku problemleri, kabus görme, iştah kesikliği gibi sorunlarla kendini gösterir. Bunun yanı sıra anneden ayrılmama konusunda aşırı direnç, yabancılardan korkma ve yalnız kaldıklarında hırçınlaşma gibi davranışlar sergileyebilirler. 3-6 yaş aralığındaki çocuklar ise aynı belirtileri göstermekle birlikte önceki gelişim evrelerine gerileme (Örneğin; parmak emmek, altını 1slatmak, konuşmada bozukluklar.), agresif tavırlar, içe kapanıklık ve sessizleşme gibi durumlar da gözlemlenebilir. Tüm bunların yanı sıra travmaya sebep olan olayın bazı yönlerini yansıtan oyunlar oynama ve olayları tekrar canlandırma gibi davranışlarda sıkça görülebilir. Dört yaşlarından sonra, çocuklarda belirginleşmeye başlayan duyguların başındasuçluluk ve utanç duyguları gelmekte ve bu duygular belirginleşmeye başlamaktadır. Bu yaştaki çocuklarda benmerkezci ve somut düşünce yapıları mevcuttur. Bu düşüncelerden dolayı çocuklar kendilerini dünyanın ve yaşanan olayın merkezinde görebilirler. Bu durum travma geçiren çocukların başlarına gelen bütün olaylardan kendilerini sorumlu görme ve kendilerini suçlu hissetme eğilimlerini arttırabilir. (Akt. Erden ve Gürdil,2009). Okul öncesindeki dönemde bulunan çocuklarda; devamlı savaşla ilgili sorular sorma, savaşlarla ilgili abartılı öyküler anlatma, yaşam şartlarındaki değişikliklere adapte olmada zorluk yaşama, karanlıktan ve hayali varlıklardan korkma gibi durumlar savaş travmasının ardından sıklıkla görülen tepkiler arasında sayılabilirler. Bununla birlikte fiziksel bir nedene bağlanamayan acılar ve ağrılar, bağırsağın kontrolünün kaybedilmesi, hareketsizlik yada hiperaktivite ve sese karşı aşırı duyarlılık gibi bedensel tepkilere de rastlanabilir (A.Ü. Çocuk Ruh Sağlığı ve Hastalıkları ABD, Bebek Birimi, 1999). 


\section{6-12 yaş okul çağl çocuklarının travmaya tepkileri}

Bu dönem çocuklarının maruz kaldıkları veya bir takım medya organları aracılığıyla gördükleri savaş yaşantılarına bağlı travmayla başa çıkmaları için kullanabilecekleri bilişsel, davranışsal ve duygusal kaynakları okul öncesi dönemi çocuklarından daha fazladır. Bununla birlikte bu dönem çocuklarının yaşadıkları olayların olumsuz yönlerine karşı verebilecekleri bir takım ortak tepkilerden de bahsetmek mümkündür. Örneğin gerileme yaşayıp önceki gelişimsel evrelere has davranışları yeniden sergileyebilir (Altını 1slatma gibi.), yalnız uyumaktan korkabilir ve odaklanıp dikkatini toplamada güçlük çekebilir. Bu tip problemler birçok alanda kendini hissettirecektir. Mesela dikkatini toplamda yaşadığı zorluklar okuldaki başarısının düşmesine neden olabileceğinden çocuk okula gitmeyi reddedebilir ve bunların sonucu olarak öğrenme ve davranış bozuklukları baş gösterebilir. Bu dönemdeki çocuk arkadaşlık ilişkilerinden veya bir takım etkinliklerden kendini geri çekebilir. Bunula birlikte pasif yada saldırgan tutumları sebebiyle arkadaşlık ilişkilerindeki bozulma da çocukta toplumsal bir soyutlanma hissine neden olabilir. Ayrıca ruhsal çöküntü, huzur yoksunluğu ve türlü fiziksel şikayetlerde görülebilir. Okul çağındaki çocuklarla okul öncesi çağındaki çocuklar arasındaki bir diğer fark ise ölümün geri dönüşünün olmadığının bilincinde olmalarıdır ve okul çağındaki çocukların ölen kişi yada kişilerin geri dönmeleriyle ilgili bir beklentileri yoktur. (Dyregrov, 2000; Thabet ve Vostanis, 1999). Yaşadıkları bu travmayla başa çıkabilmek için çeşitli oyunları, tekrardan canlandırma yöntemini ve hayal dünyalarını kullanabilirler. Çocuk hayal kurma yöntemiyle yaşadığı sarsıntıyla başa çıkabilirse, bu sarsıntının sonuçlarını değerlendirip içinde bulunduğu çarsizlik duygusuyla nasıl baş edeceğine dair çözümlerde bulabilir. Fakat çocuktaki bu bilişsel gelişmişlik seviyesi bir taraftan travmatik duruma engel olabileceğini veya bu durumla başa çıkabileceğini hayal ederken, diğer taraftan da gerekli olanı yapmamış olmaktan ötürü kendini suçlu hissetmesi gibi bir duruma sebep olabilir. (Aydın,2014).

\section{Ergenlerin travmaya tepkileri}

Ergenlik dönemi kimlik oluşturma mücadelesinin yaşandığ bir dönemdir. Tam bir yetişkin olmadıkları halde savaş yaşantısı yüzünden bir yetişkin rolü üstlenmek zorunda kalabilirler ve bunun sonucunda bir kimlik karmaşası ile karşı karşıya kalabilirler. Hayatlarından, ebeveynlerinden, kardeşlerinden, sahip oldukları fiziksel bütünlüklerden ve bağımsızlıklarından olma gibi kaygılarla karşı karşıya kalan ergenlerde; keder, yalnızlık ve geri çekilme gibi duygular gözlemlenebilir. $\mathrm{Bu}$ depresyona eşlik eden diğer problemler ise; gerginlik, baş ve karın ağrıları gibi fiziksel yakınmalar, tekerrür eden kabuslar ve istenmeyen hayallerin akılda belirmesi olarak sayılabilir (Erden ve Gürdil,2009). Ergenlik döneminde kazanılmış olan soyut düşünme yeteneği ergenlere başlarına gelen bir olayın sonucunu birden fazla boyutta değerlendirme imkanı verir. Fakat bu çok boyutlu değerlendirme ergenlerin savaşın yıkıcı ve incitici etkilerini fark etmelerine sebep olur. Bu fark etme sonucunda ergenler geleceğe kaygılı ve karamsar bir bakış açısıyla bakabilir ve gelecekle ilgili plan yapmakta zorlanabilirler (Aydın,2014). Ergenler yaşları itibariyle bu tip bir travmanın yaşamları üzerindeki etkilerini ve uzun gelecekteki sonuçlarını anlayabilecek, bu konu hakkında çıkarımlarda bulunabilecek zihinsel olgunluktadırlar. Fakat ergenler bu travmayla başa çıkma yöntemi olarak oyun ve fantezileri kullanmak yerine madde kullanımı gibi kendilerine zarar verici riskli davranışlara yönelebilirler. Ayrıca; saldırganlık, isyankar davranışlar, anti sosyallik, okul sorunları, başarısızlık, aile ve sosyal çevre ile olan ilişkinin zayıflaması gibi gözlemlenen diğer sorunlar da bu travmaya maruz kalan ergenlerin benlik değerlerini ve kendilerine olan güven duygularını zedeleyebilir. Bunların yanı sıra ergenlerde küçük çocuklardan farklı olarak başlarına gelen olaylar arasında soyut neden sonuç ilişkisi kurabilme özelliği vardır. Fakat buna rağmen ergenlerde de çocuklardakine benzer suçluluk ve utanç duyma gözlemlenebilir. (Deveci, 2014). 


\section{SONUÇ VE ÖNERILER}

Bireylerin etnik kimlik oluşumunda mecburiyet, zorlama, dışlanma gibi olumsuz faktörlerin etkili olması ve üyesi oldukları etnik grubun daha geniş kültür tarafından olumsuz algılanması bireylerde; aşağılanma, dışlanma ötekileştirilme duygusunu hakim kılabilecektir. Bu duyguların daha geniş kültüre sahip bireylere karşı bir kin ve nefret ortamı oluşturması mümkündür. Buna bağlı olarak alt etnik yapıya mensup bireylerde saldırganlık ve şiddet eğilimleri ve suça yönelme oranı artabilir. Göç olgusunun da bireyler üzerinde bir takım etkileri vardır. Yapılan araştırmalarda (Kuşdil,2014, Akar,2014, Baş; Molu ve Ark,2017) göç yaşamış çocuklarda daha fazla ruhsal bozukluklar görüldüğü tespit edilmiştir göç yaşamamış çocuklarda bu oran oldukça azdır. Göçün kişiler üzerindeki ruhsal sonuçlarını belirleyen önemli faktörlerden başlıcaları hiç şüphesiz göçün istemli olup olmadığı ve göç sonrası uyumu kolaylaştıracak etkenlerin varlığıdır. Bu noktada göçten en çok etkilenenlerin bu göç kararının alınmasında fikirlerine danışılmayan, dolayısıyla istemsiz göç ettiği var sayılan çocukların olması kaçınılmazdır. Yüksek anksiyete depresyon, arkadaşlık ilişkilerindeki problemler, travma sonrası stres bozuklukları, hiper aktivite, düşük benlik saygısı ve düşük yaşam doyumu göç yaşayan çocuklarda görülen başlıca problemler olarak sayılabilir. (Akar,2014). Bununla beraber göçe maruz kalmış çocuklar temel alınarak yapılmış olan çalışmalar, bu çocukların zaman içinde psikolojik olarak uyum sağladığını ve uzun dönemde görülen psikolojik sorunların oranıyla yerli nüfusta görülen psikolojik sorunların oranının önemli düzeyde farklılaşmadığını ortaya koymuştur. Bu bulgular göç sonrasındaki dönemde uyum sağlamayı kolaylaştıran bir takım sistemlere başvurulabileceğine dikkat çekmektedirler. Eğitim kurumlarının göç sonrası dönemde özellikle 6-12 yaş aralığındaki çocuklar için uyum sağlamayı kolaylaştırıcı bir işleve sahip olduğu düşünülmektedir. Yeni yerleşilen çevre kolay adapte olmak için gerekli ortam veya hizmetler de eğitim kurumları tarafından sunulur. Aynı zamanda göç sonrası okul değişikliği çevre değişimini de gerektirdiğinden eğitim kurumu adaptasyon yönünden önemli bir konumdadır. Okul değişikliği göçe maruz kalan çocukların başa çıkması gereken önemli bir problem olsa da okula ve çevreye adapte olabilen çocukların göçün yıkıcı ve olumsuz tesirlerini diğerlerine nazaran daha kolay atlatabilecekleri düşünülmektedir. Öğretmenlerin bu dönemdeki çocukları içinde bulundukları duruma ve ruhsal problemlerine uygun bir tutum izlemeleri ve farkındalıklarını arttırmaları bu süreçteki çocuklar için oldukça önemli bir koruyucu faktör olacaktır. İç göçte bölgesel değişimin yanı sıra sosyal çevrenin, kültürel değerlerin ve kimi zaman lisanın değişimi de gereklidir (Uluocak,2009). Bu değişimlerin sonucunda çocuklarda olası bir takım duygusal ve davranışsal problemler görülür. Bu problemleri iyi tanımlamak ve gerekli önlemleri erken almak problemlerin büyümesini durdurabilir. Bu önlemler alınmayıp göz ardı edildiği takdirde başta önemsiz görünen adaptasyon problemleri giderek artacak ve çocuk okulda uzaklaşacaktır. Bu okuldan uzaklaşma süresinin artması durumunda ise çocuğun sokağa, maddeye ve suça yönelmesi kaçınılmaz hale gelecektir (Warfa ve ark., 2005). Savaşın çocukların mental ve fiziksel gelişimleri yönünden nedenli yıkıcı etkilere sahip olduğu bilinmektedir. Bunun yanı sıra ahlaki gelişimlerinin de fazlasıyla olumsuz etkileneceği göz ardı edilmemelidir. Savaşın sebep olduğu ahlaki yıkıma maruz kalmış çocuklar doğru- yanlış ayrımını yapamazlar.

Otorite figürlerinin sergilemiş olduğu kaba kuvveti ve şiddete bağlı eylemleri model alıp ahlaki yönden kabul edilebilir olduğunu düşünebilirler. Örnek aldıkları rol modellerin şiddete yönelik davranışlarına şahit olan çocuklarda korunmak için saldırganlığa başvurma gözlemlenebilir (Gökler, 2001). Bunun yanı sıra etraflarındaki hiddetli yetişkinlerde de bu saldırgan davranışlar pekişebilir. Bugünün savaş ve çatışma ortamında büyüyen çocukların ilerleyen zamanda etkin şiddet eylemcilerine dönüşebileceklerini söylemek çok da yanlış değildir. Savaşın yıkıcı 
yönlerine maruz kalan çocuklar için ortaya konulan psiko-sosyal teşebbüsler ne kadar kapsamlı ve yoğun olsa da savaş emarelerinin tamamıyla yok edilmesi çok zordur. $\mathrm{Bu}$ sebeple günümüzde süren politik arbedelerin en kısa sürede çözüme ulaşması çocukların ve halkın bu arbedelerden uzak tutulması ve yeniden savaş meydana gelmemesi için liderlere ve otorite figürlerine oldukça büyük işler düşmektedir (Gürdil ve Erden, 2009).

Bu çalışmada etnik kimlik göç ve savaşın çocuk ve ergenler üzerindeki etkileri doküman analizi yapılarak araştırılmıştır. Araştırmacıların farklı etnik gruplar, göç yaşayan bireyler ve savaş ve çatışmalara maruz kalmış bireyler üzerler üzerinde nicel bir araştırma yapması bulguların desteklenmesi açısından faydalı olabilecektir.

Ruh sağlığı alanında çalışan, psikolojik danışman, sosyal hizmet uzmanı, psikiyatrist ve psikologların etnik ayrımcılığa maruz kalmış, göç yaşamış ve çatışma ortamında bulunmuş ergen ve çocuklar için mesleki etkinliklerde bulunurken bu durumları göz önüne alarak uygulamada bulunmaları faydalı olacaktır.

\section{KAYNAKÇA}

Akar, A., Dağ Akpolat, D. ve Miman, M. (2014) Trait anxiety level analysis of high school students with migration in Mersin, Procedia- Social and Behavioral Sciences, 113, 143-150.

Akıllı, H. ve Dirikoç, A. (2015). Uydu kent Nevşehir'de göç çocukları. İdeal Kent Dergisi, 6(17), 252-269.

Aydın N (2014). Savaşın çocuklar üzerindeki psikolojik, sosyal ve kültürel etkileri. B. Tokuş. (Ed.), Savaş ve Çocuklar. HASUDER- Çocuk Sağlığı Çalışma Grubu HASUDER, Ankara.

Baş, M., Molu, B., Tuna, H., Baş, İ. (2017). Göç eden ailelerin sosyo-kültürel ve ekonomik değişiminin kadın ve çocuk yaşamına etkisi. İnsan ve Toplum Bilimleri Araşstırmaları Dergisi, 6 (3), 1680-169

Bee, H ve Boyd, D. (2009). Çocuk gelişim psikolojisi. Kaknüs Yayınları.

Berger, R., Pat-Horenczyk, G. ve Gelkopf, M. (2007). Schoolbased intervention for prevention and treatment of elementary-students' terror-related distress in Israel: a quasi-randomized controlled trial. Journal of Traumatic Stress, 20(4), 541- 551.

Bilgin, R (2014). Çatışma ve şiddet ortamında büyüyen çocuklar sorunu. Fırat Üniversitesi Sosyal Bilimler Dergisi, 24 (1), 135-152.

Bogdan, RC ve Biklen, SK (1982). Nitel araştırma ve eğitim. Allyn ve Bacon.

Castells, M. (2010) The power of ıdentity. Wiley- Blackwell.

Çevik, A, (2007), Politik psikoloji. Dost Kitabevi.

Deveci E (2014). Savaşta çocuk ölümleri ve yaralanmaları. B. Tokuş (Ed.), Savaş ve Çocuklar. HASUDER- Çocuk Sağlığı Çalışma Grubu, HASUDER-1, 9-25

Dyregrov, A. (2000). Çocuk, kayıplar ve yas: yetişkinler için el kitabı. (G. Güvenç, Çev.). Türk Psikologlar Derneği Yayınları.

Dyregrov, A., Gjestad, R.ve Raundalen, M. (2002). Children exposed to warfare: a longitudinal study. Journal of Traumatic Stress, 15(1), 59-68.

Erden, G, (2000), Çocuklara yönelik afet sonrası müdahaleler. Türk Psikoloji Yazıları.

Erden, G. \& Gürdil, G (2009) Savaş yaşantılarının ardından çocuk ve ergenlerde gözlenen travma tepkileri ve psiko-sosyal yardım önerileri. Türk Psikoloji Yazıları.

Erol N. ve Öner, Ö. (1999). Travmaya psikolojik tepkiler ve bunlara yaklaşım. Türk Psikoloji Bülteni, 5(14), 4049. 
Graham-Bermann, S. A. ve Seng, J. S. (2005). Violence exposure and traumatic stress symptoms as additional predictors of health problems in high-risk children. Journal of Pediatrics, 146, 349-354

Gökler, B. (2001). Terör karşısında çocuklar. Türk Psikoloji Bülteni

Gün, Z. (2006), Psikolojide göç çalışmalarında metodolojik problemler ve çözüm önerileri. Türk Psikoloji Bülteni.

Kağıtçıbaşı, Ç, (2012). Benlik, aile ve insan gelişimi. Koç Üniversitesi Yayınları.

Kuşdil, M. E. (2014). Göçün incelenmesinde sosyal psikolojik bakışın önemi: bulgaristan göçmenleri örneği. Eğitim Bilim Toplum, 12(48), 149-168

Marcia, J. E. (1994). Ego identity and object relations. J. M. Masling and R. F. Bornstein (Eds), Empirical Perspectives on Object Relations Theory. American Psychological Association.

Özcan, Z. (2012) Insan ve Toplum Bilimleri 2- Epistemolojik ve Kavramsal Sınırlar. Birleşik.

Phinney, J. (2001). Ethnic 1dentity immigration, and well being: an interactional perspective. Journal of social issues vol. 57. 493-510

Thabet, A. A. M., \& Vostanis, P. (1999). Post-traumatic stress reactions in children of war. Journal of Child Psychology and Psychiatry, 40(3), 385-391

Uluocak, G, (2009). İç göç yaşamış ve yaşamamış çocukların okulda uyumu. Dokuz Eylül Üniversitesi Buca Eğitim Fakültesi Dergisi, (26), 35-44.

Yanmış, B ve Kahraman, B. (2014). Gençlerin dini ve etnik kimlik algısı: Diyarbakır örneği. Akademik Incelemeler Dergisi, 8 (2), 117-153.

Yıldırım, A. ve Şimşek, H. (2006). Sosyal bilimlerde araştırma yöntemleri. Seçkin yayınları

Warfa, N., K. Bhui, T. Craig, S. Curtis, S. Mohamud, S. Stansfeld, ve Dĭg. (2005) "Post migration geographical mobility, mental health and health service utilization among somali refugees in the uk: a qualitative study". Health and Place 12(4): 503-515 


\section{EXTENDED ABSTRACT}

\section{Psychological Effects of Ethnic Identity, War and Immigratıon Phenomenons on Children and Adolescents}

At wars and in conflicts the most suffering and innocent ones as well are certainly children. For centuries, millions of children around the world have been victims of wars, conflicts and terrorist activities. Negative effects of these wars and conflicts on children can be said as; being crippled, killed or having relatives that are wounded or killed. Along with that, being exposed to physical, psychological and sexual violence, being used as a soldier in conflicts, being forced to migrate, being mistreated, exclusion, alienation at immigration zones, having excessive politic and nationalist tendencies, diseases, poverty, and malnourishment can be regarded as the effects of war and conflicts on children. Also, it's a possibility that the children who have migrated may have problems adapting to home and school environments. Puberty is a period of scrambling to find one's identity. Emotions like grief, loneliness, and recession can be observed in adolescents who are in fear of losing their lives, parents, sisters/brothers, physical integrities and their independence. Adolescents because of their ages, are mentally mature enough to understand the effects of this kind of trauma on their lives and possible outcomes in the far future and make interference about this topic. However, they may tend to risky behaviors that can harm them like drug usage instead of playing games or using their imaginations as a method to cope with this trauma. Furthermore; aggression, rebellious attitudes, anti-sociability, problems with school, failure, weakening relationships with family and social environment and the other observed problems like these may harm self-esteem and self-reliance of adolescents exposed to this trauma. In addition to these, adolescents have the ability to form abstract causations between cases that they had befallen, unlike children. Influence of negative factors on individuals like an obligation, compulsion, exclusion and negative perception over the ethnic group which they belong to; may make abasement, exclusion, alienation feelings dominant. In this study, the situations children and adolescents that are exposed to ethnic identity problems, war, and forced migration may face, have been tried to put into words. With this study, it is intended to raise consciousness by telling the problems that adolescents are exposed to war and forced migration will have. 